letter «B» -102 examples; letter «C» -109 ; «D»- 43 [1]. Thus the analyzed matter shows not «pure», but speech enantiosemy. For example: agaçant -1) which is annoying; 2) seductive, embraceable; charmant - 1) charming, alluring; 2) unpleasant. That is, the denotative value often remains the same, and the evaluative or emotionally expressive connotation changes. Such enantiosemes are usually figurative and expressive, so they are often used in fiction, journalism, colloquial language and contribute to a pragmatic influence on the reader or interlocutor: que le diable te patafiole! 1) God bless you; 2) the hell with you! The anonymity meaning of the enantiosemic lexical unit is expressed through the context, but it is also removed through it. Often the commentary, the remark, the author's words that introduce the direct speech clarify the word meaning, so enantiosemy is not a serious problem for communication, since all lexical units are neutralized by the linguistic situation or the context.

Therefore, in our point of view, this linguistic phenomenon of our time is more considerably to be appropriated in abovementioned field, which requires careful linguistic research.

\title{
References:
}

1. Josette Rey-Debove (Ed.); Alain Rey (Ed.); Paul Robert (1985). Le petit Robert 1: dictionnaire alphabétique et analogique de la langue française [The Petit Robert: alphabetic and analogical dictionary of the French language]. Paris: Le Robert, $2171 \mathrm{p}$.

2. Shertsl, V. I. (1973). O slovakh s protivopolozhnymi znacheniyami (ili o tak nazyvaemoy enantiosemii) [About words with opposite meanings (or so-called enantiosemy)]. Khrestomatiya po istorii russkogo yazykoznaniya, pod red. F. P. Filina [Chretomathy on the history of Russian linguistics, edited by F. P. Filin]. Moscow: High School, pp. 259-264.

3. Smushchynska, I. V., Boiko, O. O. (2012). Enantiosemiia u suchasnii frantsuzkii movi: osnovni problemy [Enantiosemy in modern French: major problems]. Problems of semantics, pragmatics and cognitive linguistics, vol. 21, pp. 440-453.

\section{SUBSTANTIVATION AS THE MAIN MANIFESTATION OF THE MORPHOLOGICAL AND SYNTACTIC METHOD IN THE CREATION OF ZOONYMS}

\section{Svitlana Florinska ${ }^{1}$}

DOI: https://doi.org/10.30525/978-9934-588-11-2_47

Various aspects of the creation of onyms in a morphological and syntactic way have been explored over the last decades by such Ukrainian linguists: M. M. Torchynskyi [9], T. I. Poliarush [7], Gh. L. Arkushyn [1], S. L. Kovtiukh [5; 6], O. L. Kyryliuk [6] and other.

\footnotetext{
${ }^{1}$ Central Ukrainian State Pedagogical University named after V. Vynnychenko, Ukraine
} 
However, the word-forming features of the zoonymiia of the Kirovograd region have been partially studied, in particular proper names resulting from the transition of one grammar class to another, which determined the relevance of our study.

Different parts of the language serve as a basis for creating zoonyms in the Kirovohrad region. In the Ukrainian language the names of animals are homonymous with adjectives, verbs, numerals, interjections however, as noted by S. L. Kovtiukh, «passing into substantive other parts of the language not only undergo transposition of grammatical categories, including gender, number and case, but also acquire semantic and grammatical categories of the noun: beings / no-beings, proper and common, specific and abstract, material names» $[5, \mathrm{p} .6]$. So due to the transition of other lexical-grammatical classes into nouns the signs of the real parts of the language are lost, and actually the zoonyms (derivative words) acquire grammatical and paradigmatic features of the noun. In Ukrainian zoonymika the morphological and syntactic way of generating names is represented by transition to nouns.

The morphological and syntactic method produced 434 zoonyms, which is $11.2 \%$ of the total amount of material that was collected in the study area.

Adjectives pass into nouns with such meaning: a) colors of animal hair: Бїлий, Сі́рий, Руди́й (Ри́жий), Вишне́вий, Синюва́тий, Те́мна, Бу́рий; b) character traits: Скаже́ний, Лю́тий, Ди́кий, Брудна́, Бу́йний, Би́стра (local швидка), Прудки́й, До́бра, Ласка́ва, Розу́мна, Хи́тра; с) physical or physiological characteristics: Вели́кий, Малий, Здоро́ва (by value - large in size - local); d) features of the appearance of the animal: Пухна́стий, Чуба́та, Жи́рна, Тенді́тна, Бо́сий, Горба́тий, Карта́ва, this group also includes complex names: Довгоно́zа, Довготеле́са, Крутоло́ба, Кривола́пий and other; e) the owner's attitude towards the animal: Люби́ма, Кра́щий; f) age characteristics: Юний, Юна.

394 names were formed based on the transition of adjectives into nouns (zoonyms), which is $91.2 \%$ within the morphological-syntactic way.

Particularly noteworthy are the nicknames of the participle origin Гуля́щяa та Зама́зана (what means dirty). Such formations are the result of the first conversion of participles into adjectives and the subsequent transition into nouns [2, p. 8]. Therefore, the scheme of the transition of the participle into the noun (zoonym) is following: stray animal by nature (participle) $\rightarrow$ stray cat (adjective) $\rightarrow$ the name of the animal is Гуля́ma (Stray) (substantive).

There are nicknames of verb origin among the studied material. Such names are preferably given to dogs. This is mostly a verb in the form of the imperative: Доганя́ŭ, Гуля́ŭ, Шуга́ŭ, Літа́ŭ, Угада́ŭ, Дава́ŭ, Заліта́ŭ, Хапа́ú, Ви́ŭ etc. This is primarily due to the command that is given by the dog owner most often. For example, the primary function of a hunting dog is to catch up a bagged or frightened beast, so they have nicknames like Доганяй, Хапа́й and other. Attack dogs are given such nicknames: Hanadáŭ, Búŭ, Шyzáŭ, Kapáŭu, that are related to their main function in the yard. In total we recorded 15 such units (3.4\%), including 13 dog names and two animal names: cat Yýxaŭ, hamster Púŭ. The names of these animals are motivated not by the owner's order, but by the name of the action that animal usually does. 
Linguist N. V. Dubova claims, that the nickname Дуна́й and similar are popular amongst hunting dogs because they resemble a verb in the prescriptive form, like an «energetic» verb [3, p. 148]. We found them among zoonyms of Kirovohrad region: Кудла́ŭ, Алаба́й, Будула́й. Such nicknames may have dual motivation, for example, the nickname Кудла́й is chosen by similarity to similar names of dogs of one owner, at the same time the second is external motivation (by the characteristic properties of the animal's hair).

Examples of the transition of quantitative numerals into nouns - proper animal names - are rare. Morphological-syntactic transformation undergoes only a quantitative numeral one, for example goat Одúн, nutria Однá, chicken Годнá (local).

Ordinal numbers also may transform in nouns, mainly the numeral the first (in various forms, dialect among them). Such nicknames can be applied to any animal (cows, sheep, goats, dogs, etc.) that are the firstlings. This fact then is a motivational incentive for naming the animal: Пе́рша, Пе́рва (local), Пе́рший, Пе́рвий (local). We fixed a single name derived from the ordinal numeral the second: Дру́zий. M. I. Siusko points out in this regard that such nicknames are interpreted mainly as tags zoonyms, but not as facts, which are conditioned by the order (sequence) of the animal's appearance in the world [8, p. 292-293].

Another motivational incentive is the orderly action of the animal, for example, the chicken Пе́рша got its nickname because the first one sat on eggs (this name is temporary). Sometimes sporadic nicknames are also motivated by other ordinal numbers, such as a spider Трина́дията. We collected 10 units in total $-2.3 \%$ within the morphological and syntactic mode of creation.

As a result of the transition, the interjections sporadically perform the function of zoonyms. Traditionally in Ukrainian linguistics the notion that onomatopoeias belong to exclamations or are a group of words adjacent to them «but do not fully merge with them, since they express neither emotion nor will» [4, p. 308]. Most scientists support this view (M. Ja. Pliushch, L. I. Matsko, V. O. Horpynych, A. S. Kolodiazhnyi and other). I. R. Vykhovanets refers interjections to the sentences [10]. According to K. I. Horodenska and I. R. Vykhovanets, the onomatopoeias are related to sentences $[11$, c. 386]. In our work we endorse the traditional notions regarding this issue, so we distinguish two groups of zoonyms derivatives for which are:

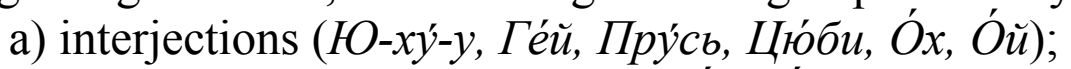

b) onomatopoeias (I-á, Xpý-Xpý, Lín-Lín, Прý-y, Гáb, Мя́в, Мé-a).

There are 13 linguistic units in total, that represent $3 \%$ of the total number of onyms formed by the morphological and syntactic method.

So, substantivation is the main manifestation of the morphological and syntactic method in the creation of zoonyms. According to a compiled and organized file cabinet, different parts of the language can be transformed into nouns (proper animal names). Typically these are adjectives. It is less productive to transform other parts of the language: verbs, numerals, interjections, including onomatopoeias. 


\section{References:}

1. Arkushyn, Gh. L. (2016). Slovotvir zoonimiv pivnichno-zakhidnoji Ukrajiny [Word formation zoonims Northwestern Ukraine]. The typology and functions of linguistic units, no. 2, pp. 5-16. (in Ukrainian)

2. Barannyk, D. Kh. (1969). Prykmetnyk [Adjective]. Suchasna ukrajinsjka literaturna mova. Morfologhija [Modern Ukrainian literary language. Morphology]. Kyjiv: Scientific thought. (in Ukrainian)

3. Dubova, N. Gh. (1980). Dejaki osoblyvosti klychok myslyvsjkykh sobak [Some features of hunting dog nicknames]. Onomastics question, vol. 14, pp. 145-149. (in Ukrainian)

4. Ghorpynych, V. O. (2004). Morfologhija ukrajinsjkoji movy [Morphology of the Ukrainian language]. Kyjiv : Academy. (inUkrainian)

5. Kovtjukh, S. L. (2002). Morfologhichna paradyghmatyka substantyvovanykh chastyn movy [Morphological paradigm of substantiated parts of language]. Scientific notes, vol. 44, pp. 5-10. (in Ukrainian)

6. Kovtjukh, S. L., \& Kyryljuk, O.L. (2010). Kinonimija v suchasnij ukrajinsjkij movi: pryncypy nominaciji ta sposoby tvorennja [Kinonymy in modern Ukrainian: nomination principles and ways of creation]. Kirovoghrad: DLAU. (in Ukrainian)

7. Poljarush, T. I. (2009). Mikrotoponimija i miscevyj lingvaljnyj kontekst [Microtoponymy and local lingual context]. Studia Slovakistica, vol. 10, pp. 372-384. (in Ukrainian)

8. Sjusjko, M. I. (2014). Pytannja suchasnoji ukrajinsjkoji literaturnoji ta zhyvorozmovnoji movy [Problems of modern Ukrainian language and folk language]. Uzhghorod : Ghrazhda. (in Ukrainian)

9. Torchynsjkyj, M. M. (2008). Struktura onimnogho prostoru ukrajinsjkoji movy [Structure of proper names of the Ukrainian language]. Khmeljnycjkyj : Avist. (in Ukrainian)

10. Vykhovanecj, I. R. (1993). Ghramatyka ukrajinsjkoji movy. Syntaksys [Grammar of the Ukrainian language. Syntax]. Kyiv : Lybidj. (in Ukrainian)

11. Vykhovanecj, I. R., \& Ghorodensjka, K. Gh. (2004). Teoretychna morfologhija ukrajinsjkoji movy [Theoretical morphology of the Ukrainian language]. Kyiv : Pulsars. (in Ukrainian)

\section{THE IMPORTANCE OF ONOMASTIC ANALYSIS IN THE STUDY OF LITERARY WORKS}

\section{Anna Shotova-Nikolenko ${ }^{1}$}

DOI: https://doi.org/10.30525/978-9934-588-11-2_48

In the system of general theory of artistic speech, which is characterized by versatility, a variety of creative approaches to the literary texts and idiostyles of their authors, from the second half of the twentieth century was actively developed one of its important branches - the theory of literary onomastics, which was initiated by significant works of the scientists Yu. O. Karpenko, V. M. Mikhailov, O. V. Superanskaya, etc. The onomastic researches will always have scientific relevance, novelty and perspective, since the studying of proper names is inexhaustible in the illimitable ocean of the world literature.

\footnotetext{
${ }^{1}$ Odesa State Environmental University, Ukraine
} 